relationships with Ketilidian supracrustals in the Ivigtut region, South-West Greenland. Rapp. Grønlands geol. Unders. 8, 21 pp.

Nielsen, B. L. 1976: Economic minerals. In Escher, A. \& Watt, W. S. (edit.) Geology of Greenland, 460-487. Copenhagen: Geol. Surv. Greenland.

Watterson, J. 1965: Plutonic development of the Ilordleq area, South Greenland. I: Chronology, and the occurrence and recognition of metamorphosed basic dykes. Bull. Grønlands geol. Unders. 51, 147 pp.

\title{
Regional geological investigations in the Ammassalik district, South-East Greenland
}

\author{
Feiko Kalsbeek and Troels F. D. Nielsen
}

One of GGU's main expeditions in 1986 took place in July and August in the Ammassalik (Angmagssalik) district of South-East Greenland between $64^{\circ}$ and $67^{\circ} \mathrm{N}$ (fig. 1). Until this summer the geology of this region was known only superficially, mainly from reconnaissance by Wager (1934), from local mapping projects by the University of Birmingham in the sixties and early seventies (Wright et al., 1973) and from coastal reconnaissance carried out by GGU under the direction of D. Bridgwater, mainly in the seventies (e.g. Bridgwater \& Gormsen, 1968; Bridgwater et al., 1977; Bridgwater \& Myers, 1979). The present work had two major aims: to provide regional data for the preparation of the 1:500 000 map sheet 14 and to obtain an impression of the area's economic mineral resources. Much of the summer's work was based on helicopter support which made it possible to study large inland areas that had not been visited previously.

\section{Organisation}

The operations in the Ammassalik district were performed in close co-operation with the Geodætisk Institut (GI) which carried out surveying and gravimetric measurements in the region between Ammassalik and Scoresby Sund (around $70^{\circ} \mathrm{N}$ ). Because of this co-operation it was possible for about three weeks to have GGU parties in the field in the Kangerdlugssuaq area and farther north along Blosseville Kyst. Some aspects of this work are reported upon by Brooks et al. (this report).

Two helicopters were chartered for the operation from Uni-fly, Denmark, through Greenlandair Charter A/S: a McDonald-Douglas (Hughes) $500 \mathrm{E}$ (chartered by GGU), and an Aerospatiale Ecureuil 350 B1 (chartered by GI). The use of the helicopters was shared by GGU and GI. The helicopters were transported between Ammassalik and Ålborg, Denmark, by KNI, the Greenlandic trading organisation.

The work in the Ammassalik region was carried out from two coastal base camps, a main camp erected and manned by GGU a few kilometres north of Ammassalik (c. $\left.65^{\circ} 40^{\prime} \mathrm{N}\right)$ and, for a few weeks at the beginning of the season, from a camp set up and organised by GI at Nigertuluk (c. $66^{\circ} 22^{\prime} \mathrm{N}$ ). The Ammassalik base staff consisted of Jørgen Lau and Palle Bay 


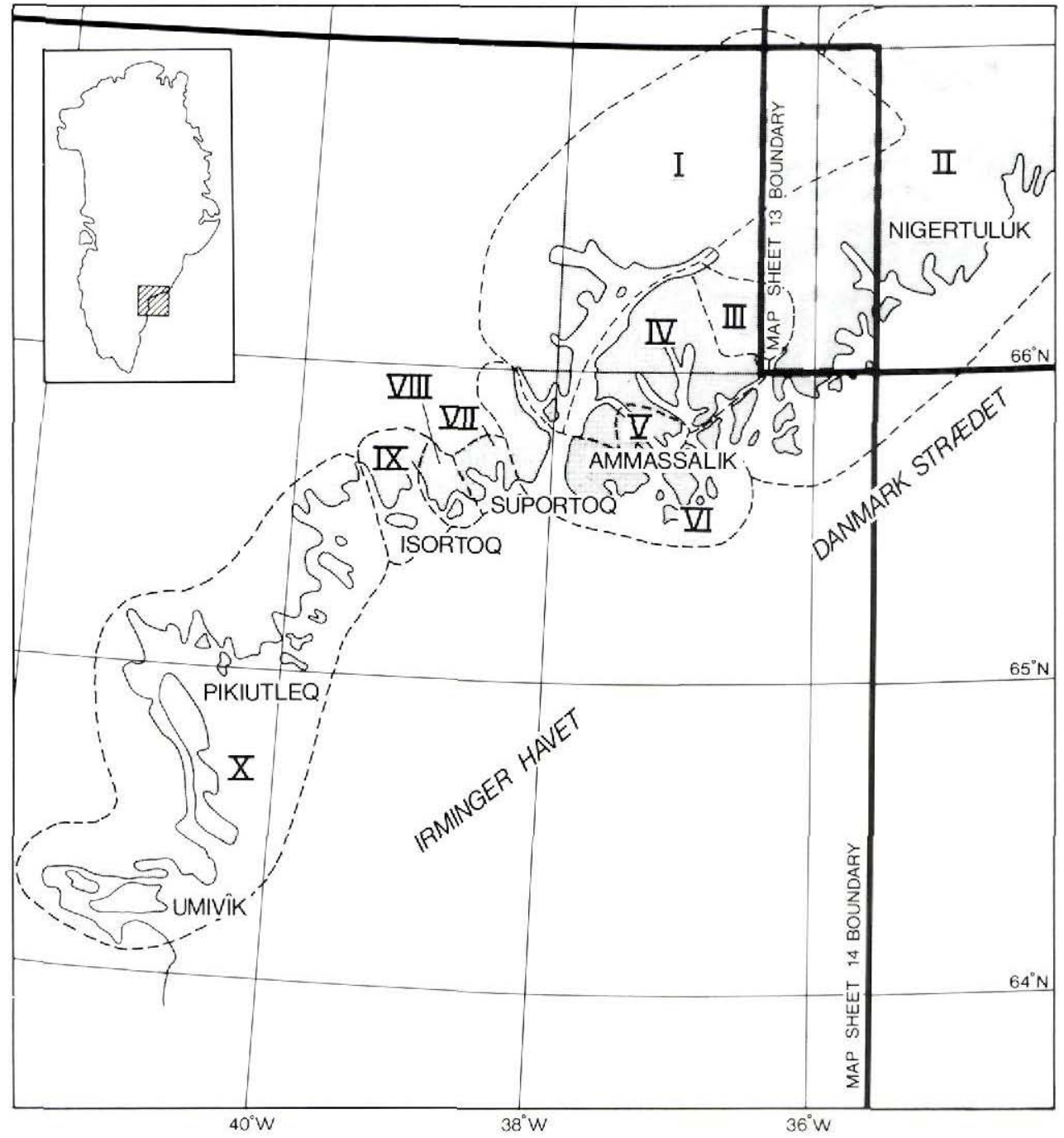

Fig. 1. Sketch map of the Ammassalik district showing the areas investigated by the different teams of geologists, and the margins of GGU's 1:500 000 map sheets 13 and 14. I: J. C. Escher \& R. P. Hall; II: P. R. Dawes \& N. J. Soper; III: B. Chadwick \& J. N. Soper; IV: B. Chadwick \& V. N. Vasudev; V: T. F. D. Nielsen \& V. N. Vasudev; VI: C. R. L. Friend \& A. P. Nutman; VII: B. Chadwick \& V. N. Vasudev; VIII: C. R. L. Friend \& A. P. Nutman; IX: J. C. Escher \& R. P. Hall; X: J. C. Escher, C. R. L. Friend \& R. P. Hall.

(GGU; materials), Inger Thomsen (GGU; cook), Morten Hoff Ærsøe (student, Technical University of Denmark; radio communications) and Vibeke Kalsbeek (student, University of Copenhagen; general assistant). The helicopter pilots for most of the season were Lennart Rahm (SAAB, Sweden) and Staffan Forsstedt (Liniefly, Sweden). Maintenance of the 
GGU chartered helicopter was carried out by Frede Stadsgaard and Henning Jørgensen (employed through Uni-fly). Most of the preparations for the project were carried out by $T$. F. D. Nielsen (GGU), later joined by F. Kalsbeek (GGU). Co-ordination in the field was the responsibility of F. K., assisted by T. F. D. N.

At the end of the season (August 31), after most expedition members had travelled home, the Ammassalik camp was hit by a violent storm with wind speeds up to 120 knots (a socalled 'piterak') which resulted in severe loss of GGU equipment. Fortunately, no scientific results were lost.

\section{Geology}

Apart from the authors, the following geologists took part in the investigation: B. Chadwick (University of Exeter, U. K.), P. R. Dawes (GGU), J. C. Escher (GGU), C. R. L. Friend (Oxford Polytechnic, U. K.), R. P. Hall (Portsmouth Polytechnic, U. K.), A. P. Nutman (Memorial University, Newfoundland, Canada), N. J. Soper (University of Sheffield, U. K.), and V. N. Vasudev (Department of Mines and Geology, Bangalore, India). The areas investigated by the different geologists are shown on fig. 1. This group was joined for part of the season by C. K. Brooks (University of Copenhagen) and G. Stenstrop (University of Aarhus, Denmark) to make a special investigation of mineral occurrences of possible economic interest. The geologists worked in parties of two or three and frequent contacts and discussions ensured rapid exchange of results and views. The area to be covered was large: c. $300 \mathrm{~km}$ from north to south, and large parts of the terrain were highly inaccessible even by helicopter. Detailed investigations were therefore restricted to small areas, while most of the terrain was studied only summarily.

Detailed results of this summer's work will be published in a separate volume of GGU's report series. The following simplified geological outline is based on the earlier descriptions of Wright et al. (1973) and Bridgwater \& Myers (1979), together with the results of the 1986 expedition mainly obtained by our colleagues. Because of the way the work was organised it is difficult to attach a particular name to a particular result, and this is therefore not attempted. Our results are to a large extent in agreement with those of the earlier investigations referred to above, but in several respects our interpretation is different, as outlined below.

\section{Main rock units}

Most of the area consists of variable, complexly folded, polyphase grey orthogneisses and migmatites. Preliminary isotope work has shown that most, if not all, of these are of Archaean age (Pedersen \& Bridgwater, 1979; P. N. Taylor, personal commumication, 1986; for further details see Bridgwater \& Myers, 1979). A second major component of the area is formed by a range of supracrustal rocks, mainly metasediments (metapelitic paragneisses, marbles, quartzites) but also including amphibolites. These may form layers up to a kilometre or more thick, which in some instances can be followed for many kilometres. The age of deposition of the metasediments is not known. Bridgwater \& Gormsen (1968) and Wright et al. (1973) regarded them as being younger than the quartzofeldspathic orthogneisses and part of an originally unconformable cover on the Archaean basement. Bridgwater et al. 
(1977) and Bridgwater \& Myers (1979), on the contrary, regarded the supracrustal units as Archaean and older than the gneisses. Wager (1934) had earlier adopted this view but expressed caution as to the usefulness of field observations in this respect. The work of this summer has not provided irrefutable evidence for either of these views, and there is no agreement among the participating geologists about the relative ages of the gneisses and the metasediments.

The supracrustal rocks in the Ammassalik district are in several respects different from those found in the Archaean craton: predominance in the former of metasedimentary over metavolcanic rocks; the presence of major marble units; the scarcity or absence of basic dykes in the supracrustals compared to their relative abundance in the surrounding gneisses (see below), and the relatively good state of preservation of the metasedimentary rocks they are strongly recrystallised but often hardly or not at all migmatised, and locally they show well-preserved primary sedimentary structures. These differences to most supracrustal units in the Archaean craton were used to argue for a younger age of the supracrustal rocks relative to the gneisses. On the other hand, the occurrence of gneiss sheets within some supracrustal units and of locally abundant inclusions of metasedimentary material in the gneisses favour an originally intrusive relationship between the grey gneisses and the supracrustal rocks, and hence suggest an Archaean age for the latter. It is of course possible that both Archaean and Proterozoic supracrustal rocks are present in the region but the large mappable units dominated by metasediments are probably all of broadly similar age. Samples were collected for isotope study which it is hoped will solve the issue.

A minor but ubiquitous rock component is formed by suites of basic dykes, often strongly deformed and metamorphosed, which are locally very abundant, especially in the grey orthogneisses. These rocks have been correlated by Bridgwater and co-workers with early Proterozoic mafic dykes in West Greenland, and if this correlation is correct (we found no reason to doubt this view) the degree of deformation and grade of metamorphism of the dykes can be used to study the Proterozoic tectono-metamorphic history of the area (cf. Korstgård, 1979). As mentioned above, such dykes are rare in the supracrustal rocks which may indicate that the metasediments are younger than most of the dykes, although it is also possible that their rarity is due to differences in the physical properties of the gneisses and the metasediments. None of the dykes in the northern part of the area seem to have a well preserved igneous mineralogy. They are variably deformed and all appear to be partly metamorphosed to garnet-amphibolite assemblages, although some dykes have preserved igneous textures.

In the centre of the area, around the town of Ammassalik, a suite of intrusive hypersthene-bearing dioritic to granodioritic rocks (the Angmagssalik charnockite complex Bridgwater \& Myers, 1979) appears to have a Proterozoic age (Chessex, unpublished data, quoted in Pedersen \& Bridgwater, 1979; P. N. Taylor, personal communication, 1986). These rocks are not cut by mafic dykes. The complex was intruded into metasedimentary rocks with thin units of Archaean gneisses and caused widespread anatexis. The resulting rocks are commonly rich in garnet and comprise the 'garnet granite gneisses' of Wager (1934). Rb-Sr isotope work on these host rocks has yielded poorly fitted isochrons suggesting partial isotopic homogenisation c. $1850 \mathrm{Ma}$ ago (Pedersen \& Bridgwater, 1979). The rocks of the Angmagssalik igneous complex are variably deformed, but commonly only to a minor degree, and they are regarded as being broadly synkinematic with late stages of the regional deformation.

The youngest Precambrian rocks in the Ammassalik district are a suite of post-tectonic 
gabbros, diorites and granites that form sharply cross-cutting plutons dated at $c .1580 \mathrm{Ma}$ (Pedersen \& Bridgwater, 1979; Taylor et al. 1984).

The area is cut by a number of Tertiary basic dykes which are most common in the coastal area. An intrusive alkaline complex was discovered in the northern part of the region at $66^{\circ} 30^{\prime} \mathrm{N}$; this is the southernmost of the known series of Tertiary igneous centres along the coast.

\section{Structural development}

According to Bridgwater \& Myers (1979) the rocks in the Ammassalik district form part of the Nagssugtoqidian mobile belt, defined in West Greenland by Ramberg (1948), and they state that "The tectonic and magmatic activity in the Nagssugtoqidian continued after the close of Archaean high grade metamorphism for approximately 1000 m.y." (op. cit. p. 16). According to these authors late Archaean tectonic activity, termed 'Nag. 1' deformation, was concentrated in a number of E-W trending shear zones with a dextral transcurrent sense of movement and was associated with retrogression of the Archaean gneisses from granulite to amphibolite facies. Formation of the shear belts was followed in the central part of the belt by emplacement of syntectonic calc-alkaline rocks, the 'Blokken gneisses', which were described as having commonly preserved primary igneous textures. Based on preliminary whole-rock $\mathrm{Pb}-\mathrm{Pb}$ data these were thought to have been emplaced c. $2400 \mathrm{Ma}$ ago (Bridgwater et al., 1978). The mafic dykes mentioned above were, according to Bridgwater \& Myers (1979), intruded over a long period of time from $c .2600$ to $c .1900$ Ma ago. Deformation and metamorphism of these mark the effects of the Proterozoic late Nagssugtoqidian ('Nag. 2 ') activity which resulted in the formation of north-dipping shear zones in the southern part of the district and of complex fold interference patterns refolding the Nag. 1 structures in the northern part. Emplacement of the Angmagssalik igneous complex was presumed to have taken place during Nag. 2 .

Investigations this summer have led to doubt regarding several aspects'of this scenario:

(1) Although there is no reason to doubt the importance of Proterozoic tectono-metamorphic activity, no compelling evidence was found to correlate the rocks in the Ammassalik district with those of the Nagssugtoqidian mobile belt in West Greenland. The major characteristic of the west coast Nagssugtoqidian is the predominance of ENE-trending structures, in part associated with shear zones. This feature has been used to differentiate the Nagssugtoqidian from the Rinkian mobile belt to the north which is characterised by dome and basin structures (Escher et al., 1976; Escher \& Pulvertaft, 1976). The rocks in the Ammassalik area do not have a preferred regional orientation like those of the Nagssugtoqidian in West Greenland and the main structures are more reminiscent of those in the Rinkian mobile belt.

Apart from the obvious structural difference from the Nagssugtoqidian at the west coast, geomagnetic investigations across the Inland Ice (Thorning, 1986) do not support the view that there is a structural continuity between the east and west coast Nagssugtoqidian as suggested on many previous geotectonic compilations (e.g. Escher \& Watt, 1976).

(2) Bridgwater \& Myers $(1979$, p. 16) apply the term 'Nagssugtoqidian' to "a restricted geographical area affected by a distinct series of tectonic, magmatic and metamorphic events which together make up a structural province". This usage would appear to make it difficult to map a precise boundary to the mobile belt without defining this as either a tectonic, a magmatic or a metamorphic boundary. Myers et al. (1979) and Bridgwater \& Myers (1979, 
fig. 1) draw a sharp boundary in the northern part of the Ammassalik district between the Archaean craton to the north and the 'Nagssugtoqidian' to the south, the Nagssugtoqidian being characterised by Nag. 1 deformation which caused retrogression of the Archaean granulite facies gneisses. The boundary was chosen to coincide with a major Nag. 1 shear zone. At the coast there is indeed a distinct shear zone, but inland there is no evidence to substantiate important geological changes along the line indicated. The present interpretation is of a wide (c. $50 \mathrm{~km}$ at least) transitional zone between presumed Archaean granulite facies rocks in the north and amphibolite facies rocks in the area north of Ammassalik. Parts of the 'grey' (amphibolite facies) gneisses were apparently formed by retrogression of granulite facies gneisses, sometimes, but not exclusively, in late Archaean shear zones; other grey gneisses appear never to have been at granulite facies.

We would prefer to define the boundaries of the mobile belt in terms of the limits of Proterozoic tectono-metamorphic influence (see e.g. Kalsbeek, 1979). These limits may be established by petrographic study of the (presumably Proterozoic) basic dykes or by K-Ar analysis of hornblende and biotite in the gneisses, or by mapping isograds in the supracrustal rocks should isotope data show these to be of Proterozoic age. It is possible that the northern limit of Proterozoic metamorphism is much farther north than the boundary of the mobile belt as defined by Bridgwater \& Myers (1979). Apart from the Tertiary dykes, all dykes examined seem to some degree affected by later deformation and metamorphism, but this will have to be substantiated by petrographic evidence.

(3) No evidence emerged to maintain the 'Blokken gneisses' as a separate post-tectonic (with respect to the Archaean evolution of the area) calc-alkaline intrusive complex. The rocks mapped by Bridgwater et al. (1978) and Bridgwater \& Myers (1979) as Blokken gneisses do not differ in any significant way from the surrounding grey gneisses, and discordant relationships with the gneisses (Myers, 1984) could not be confirmed. Recent zircon $\mathrm{U}-\mathrm{Pb}$ data by $\mathrm{B}$. Tauber Hansen (personal communication, 1986) and whole-rock $\mathrm{Pb}-\mathrm{Pb}$ results of P. N. Taylor (personal communication, 1986) which supersede the earlier provisional data (Bridgwater et al., 1978) support the view that the Blokken gneisses are normal Archaean orthogneisses, reworked during the Proterozoic. The non-existence of a separate phase of early Proterozoic syntectonic calc-alkaline igneous activity removes one of the arguments for continued magmatic and tectonic activity after the end of the Archaean.

(4) The age of the main supracrustal rocks is a key feature in the structural development of the area. The present writers are inclined to believe that they are early Proterozoic but, as mentioned previously, this needs isotopic confirmation because the field evidence is not conclusive. If this view is correct, the notion of continuous tectonic and magmatic activity for more than 1000 million years would be untenable because a long period of uplift, erosion, peneplanation and sedimentation of pelitic and calcareous sediments would have to be allowed for. In that case the 'Nag. 1' shear zones (much less common than anticipated) could be equivalents of the late Archaean shear zones that are common to many parts of the Archaean in Greenland, including areas that show no evidence of Proterozoic reworking. The Ammassalik district then appears to be another region like the Nagssugtoqidian and Rinkian mobile belts of West Greenland in which normal Archaean rocks were overprinted by much later Proterozoic tectono-metamorphic and igneous activity. 


\section{Economic geology}

The Ammassalik district contains several occurrences of possible economic mineral deposits and industrial minerals. The most important of these are listed below. Further details will be reported on a later occasion.

(1) A dunite body east of Sermilik fjord contains large amounts of olivine sand that may have interest as a refractory material. Minor amounts of asbestos and chromite are also present, and soapstone from this locality has been used by the local population for artistic purposes (stone carvings).

(2) The metasediments contain disseminated sulphides (mainly pyrite and pyrrhotite) and local large concentrations of graphite, some horizons containing up to 50 per cent of this mineral.

(3) A gabbro complex assumed to be related to the post-tectonic intrusions contains concentrations of sulphides and may deserve further investigation.

(4) Several gemstone occurrences were found, some of which might be exploited on a small scale.

(5) Garnet-rich sands were found on beaches near outcrops of the garnet-rich gneisses that surround the Angmagssalik igneous complex.

(6) Some rock types might be quarried as building stone or road material.

Samples of these and several other showings were collected for laboratory investigation. More detailed study in the field will be necessary for a better evaluation of promising localities. The region is reasonably accessible and several localities for graphite, olivine sand and building stone are near open water in the summer months.

\section{References}

Bridgwater, D., Davies, F. B., Gill, R. C. O., Gorman, B. E., Henriksen, N. \& Watterson, J. 1977: Field mapping in the Nagssugtoqidian of South-East Greenland. Rapp. Grønlands geol. Unders. 85, 74-83.

Bridgwater, D., Davies, F. B., Gill, R. C. O., Gorman, B. E., Myers, J. S., Pedersen, S. \& Taylor, P. (N.) 1978: Precambrian and Tertiary geology between Kangerdlugssuaq and Angmagssalik, East Greenland. A preliminary report. Rapp. Grønlands geol. Unders. 83, 17 pp.

Bridgwater, D. \& Gormsen, K. 1968: Precambrian rocks of the Angmagssalik area, East Greenland. Rapp. Grønlands geol. Unders. 15, 61-71.

Bridgwater, D. \& Myers, J. S. 1979: Outline of the Nagssugtoqidian mobile belt of East Greenland. Rapp. Grønlands geol. Unders. 89, 9-18.

Escher, A., Sørensen, K. \& Zeck, H. P. 1976: Nagssugtoqidian mobile belt in West Greenland. In Escher, A. \& Watt, W. S. (edit.) Geology of Greenland, 77-95. Copenhagen: Geol. Surv. Greenland.

Escher, A. \& Pulvertaft, T. C. R. 1976: Rinkian mobile belt of West Greenland. In Escher, A. \& Watt, W. S. (edit.) Geology of Greenland, 105-119. Copenhagen: Geol. Surv. Greenland.

Escher, A. \& Watt, W. S. 1976: Summary of the geology of Greenland. In Escher, A. \& Watt, W. S. (edit.) Geology of Greenland, 11-16. Copenhagen: Geol. Surv. Greenland.

Kalsbeek, F. 1979: Rb-Sr isotope evidence on the age of the Nagssugtoqidian orogeny in West Greenland, with remarks on the use of the term 'Nagssugtoqidian'. Rapp. Grønlands geol. Unders. 89, 129131.

Korstgård, J. A. 1979: Metamorphism of the Kangâmiut dykes and the metamorphic and structural evo- 
lution of the southern Nagssugtoqidian boundary in the Itivdleq-Ikertôq region, West Greenland. Rapp. Grønlands geol. Unders. 89, 63-75.

Myers, J. S. 1984: The Nagssugtoqidian mobile belt of Greenland. In Kröner, A. \& Greiling, R. (edit.) Precambrian tectonics illustrated, 237-250. Stuttgart: E. Schweizerbart'sche Verlagsbuchhandlung.

Myers, J. S., Austrheim, H., Gill, R. C. O., Gorman, B. E. \& Rex, D. C. 1979: Field work on the Nagssugtoqidian boundary north of Angmagssalik and Tertiary igneous rocks of Kialineq and Kap Gustav Holm, East Greenland. Rapp. Grønlands geol. Unders. 95, 82-85.

Pedersen, S. \& Bridgwater, D. 1979: Isotopic re-equilibration of Rb-Sr whole rock systems during reworking of Archaean gneisses in the Nagssugtoqidian mobile belt, East Greenland. Rapp. Grønlands geol. Unders. 89, 133-146.

Ramberg, H. 1948: On the petrogenesis of the gneiss complexes between Sukkertoppen and Christianshaab, West Greenland. Meddr dansk geol. Foren. 11, 312-327.

Taylor, P. N., Jones, N. W. \& Moorbath, S. 1984: Isotopic assessment of relative contributions from crust and mantle sources to the magma genesis of Precambrian granitoid rocks. Phil. Trans. R. Soc. Lond. A 310, 605-625.

Thorning, L. 1986: A decade of geophysical surveying in Greenland. Rapp. Grønlands geol. Unders. 128, 123-133.

Wager, L. R. 1934: Geological investigations in East Greenland. Part 1. General geology from Angmagsalik to Kap Dalton. Meddr Grønland 105(2), $46 \mathrm{pp}$.

Wright, A. E., Tarney, J., Palmer, K. F., Moorlock, B. S. P. \& Skinner, A. C. 1973: The geology of the Angmagssalik area, East Greenland and possible relationships with the Lewisian of Scotland. In Park, R. G. \& Tarney, J. (edit.) The early Precambrian of Scotland and related rocks of Greenland, 157-177. Univ. Keele.

\title{
Reconnaissance for economic minerals in the Kangerdlugssuaq area, East Greenland
}

\author{
C. K. Brooks, H.-K. Schønwandt and G. Stenstrop
}

As an intergral part of GGU's work in East Greenland in 1986 (Kalsbeek \& Nielsen, this report) a party visited the Kangerdlugssuaq area with a view to assessing its economic potential. Logistic support was shared with the Geodetic Institute. During most of the period spent in the field area (27 July to 12 August) Stenstrop, assisted by Henrik Krarup (a student assistant), worked on Flammefjeld, a porphyry molybdenum prospect earlier investigated by the Northern Mining Company of Copenhagen (Geyti \& Thomassen, 1984), while Brooks and Schønwandt investigated other targets and co-operated closely with Platinova Resources Ltd of Toronto who have a concession in the area.

Kangerdlugssuaq is an area of Archaean gneisses which was subject to intense magmatic activity in the early Tertiary when the present continental margin was located over the hot spot which now lies under Iceland. The geology has recently been reviewed by Brooks \& Nielsen (1982), where localities mentioned here can be identified.

Flammefjeld is a $600 \times 800 \mathrm{~m}$ subvolcanic complex intruding syenites of the Kangerdlugssuaq intrusion and its satellite, the Snout Series. It consists of a breccia pipe containing fragments of the host syenite in its various forms and also fragments of felsite porphyry 